\title{
The influence of selected sociodemographic data on coping with stress by parents of hospitalized children
}

\author{
MAŁGORZATA ELŻBIETA STARCZEWSKA ${ }^{1, A, c}$, ANNA WA DOOCH ${ }^{2, B, D}$, ANNA RECZYŃSKA ${ }^{1, c, E}$, \\ KATARZYNA AUGUSTYNIUK ${ }^{1, E, F}$, MARZANNA STANISŁAWSKA ${ }^{1, E, G}$, ELŻBIETA GROCHANS ${ }^{1, A, D}$
}

${ }^{1}$ Department of Nursing, Pomeranian Medical University in Szczecin

${ }^{2}$ Student Scientific Organization at the Department of Nursing, Pomeranian Medical University in Szczecin

A - Study Design, B - Data Collection, C - Statistical Analysis, D - Data Interpretation, E - Manuscript Preparation, F - Literature Search, G - Funds Collection

Summary Background. A child's illness is a major stress-inducing factor for parents. It alters interpersonal relationships in and outside the family unit and weakens the sense of safety. In stressful situations, everyone adopts certain behaviors that are defined as a stress-coping style.

Objectives. The aim of the study was to analyze factors which contribute to the choice of a stress-coping style by parents of hospitalized children.

Material and methods. This survey-based study was conducted among 292 parents of children hospitalized in the General and Neurological Pediatric Ward of the Voivodeship Independent Public Hospital in Gorzow Wielkopolski. The research instruments were: the Coping Inventory for Stressful Situations (CISS) - a standard questionnaire for measuring one's ability to cope with difficult situations, developed by N. S. Endler \& J. D. A. Parker, and a questionnaire of the authors' own design.

Results. The parents of hospitalized children employed all types of stress-coping strategies, but task-oriented coping was the most common (41.10\%). Education was the only sociodemographic factor that had a statistically significant influence on the parents' choices of stress-coping styles $(p<0.01)$.

Conclusions. 1. Most frequently, parents of ill and hospitalized children adopt a task-oriented coping style. 2. Parents' education significantly contributes to their choice of a stress-coping style.

Key words: stress, parents, hospitalized child, stress-coping style.

Starczewska ME, Wałdoch A, Reczyńska A, Augustyniuk K, Stanisławska M, Grochans E. The influence of selected sociodemographic data on coping with stress by parents of hospitalized children. Fam Med Prim Care Rev 2017; 19(1): 59-61, doi: 10.5114/fmpcr.2017.65093.

\section{Background}

A child's illness, especially chronic or incurable, is a highly stressful event in the life of parents. It changes existing relationships between family members, their relations with the environment, roles, system of values, and it weakens the feeling of safety $[1,2]$. During a child's stay in the hospital, parents experience a constant presence of the feeling of stress and states of anxiety fearing for their child's life, which, in turn, can trigger depression and a breakdown of family and social ties [3]. The experienced stress interferes with the parent-child relationship, often leading to parents' emotional maladjustment [4], which can reflect onto children's health and their recovery speed [5]. When a stressful situation occurs, each person undertakes a specific activity, which is defined as a stress-coping style.

\section{Objectives}

The aim of the study was to analyze factors which contribute to the choice of a stress-coping style by parents of hospitalized children.

\section{Material and methods}

This survey-based study was conducted among 292 parents of children hospitalized in the General and Neurological Pediatric Ward of the Voivodeship Independent Public Hospital in Gorzow Wielkopolski. The study involved 292 parents of hospitalized children.
The study included a diagnostic questionnaire method, and the research instruments were the Coping Inventory for Stressful Situations (CISS) - a standard questionnaire for measuring one's ability to cope with difficult situations, developed by N. S. Endler \& J. D. A. Parker, used in its Polish version made by Strelau, Jaworowska, Wrześniewski and Szczepaniak [6], and an original questionnaire, containing sociodemographic data, prepared by the authors. The CISS questionnaire consists of 48 statements that concern different behaviors undertaken by people in stressful situations. It distinguishes 3 basic stress-coping styles: a task-oriented style (SSZ) that consists in taking active measures aimed at solving a problem, an emotion-oriented style (SSE) that characterizes people whose behavior in a stressful situation is focused on themselves and their own emotional experiences, and an avoidance-oriented style (SSU), where such people are characterized by a tendency to avoid thinking about and experiencing difficult situations. This last style contains 2 subtypes - the first oriented at engaging in substitutional activities (ACZ), and the second seeking social contacts (PKT). Each subject was asked to select a response on a scale of $1-5$, where 1 means "never" and 5 - "always", which characterized the frequency of the behaviors or phenomena listed in the statements. Particular styles and subtypes are measured using a corresponding subscale. The so-called raw results obtained are converted into sten scores by gender and age of the subject. The sten scale range is between 1 and 10. A sten score from 1 up to 3 is a low result that indicates a lack of tendency to a particular stress-coping style. Sten scores of 4,5 and 6 are average results showing a moder- 
ate tendency to a particular style. A sten of 7 or above is a high score, interpreted as a strong tendency to a given style [6].

StatSoft Statistica 10 PL was used for the statistical analysis. The Kruskal-Wallis test was used for multiple independent groups, and the chi-square test was used for variables expressed on a nominal scale. The normality of distribution was confirmed by the Saphiro-Wolf test. The accepted level of statistical significance was $a=0.05$.

The study received a positive opinion from the Bioethics Committee of the Pomeranian Medical University.

\section{Results}

The average age of parents was $31.72 \pm 6.59$, where the minimum age was 18 and the maximum 59. Most of the subjects were women (84.25\%), married couples (67.47\%), people with higher education (44.86\%) and people living in cities of more than 100,000 residents ( $45.89 \%)$.

The analysis of results of the CISS scale showed that for the task-oriented stress-coping style (SSZ), all of the results were within the range of 1-10 stens. The dominant was equal to 5, and this result was obtained by $22 \%$ of the subjects. For the emotion-oriented stress-coping style (SSE), a full range of sten points was observed as well. Half of the respondents obtained a value between 3 and 6 points. The dominant was equal to 6 , and this result was obtained by $26 \%$ of women. In the last of the scales - avoidance-oriented scale (SSU) - a full range of possible values was obtained as well. Multiple dominant forms appeared here. Values of both 5 and 6 were obtained by $20 \%$ of the subjects (Table 1). In the ACZ subscale, after conversion to stens, a value from 1 up to 10 was obtained. The dominant was equal to 5 , and this result was obtained by $27 \%$ of the subjects.
In the PKT subscale, the dominant was 6, and such a value was obtained by $21 \%$ of the subjects.

\begin{tabular}{|c|c|c|c|c|}
\hline Variable & $X^{2} \pm S D$ & Min-Max & $Q_{1}-Q_{3}$ & Me \\
\hline TOC & $6.23 \pm 2.03$ & $1-10$ & $5-8$ & 6 \\
\hline EOC & $5.05 \pm 2.11$ & $1-10$ & $3-6$ & 5 \\
\hline $\mathrm{AOC}$ & $5.26 \pm 2.03$ & $1-10$ & $4-7$ & 5 \\
\hline Distraction & $5.01 \pm 1.99$ & $1-10$ & $4-6$ & 5 \\
\hline Social Diversion & $5.88 \pm 2.00$ & $1-10$ & $5-7$ & 6 \\
\hline
\end{tabular}

$X^{2}$ - chi-square test result, SD - standard deviation, Min - minimum, Max - maximum, $\mathrm{Q}_{1}$ - lower quartile, $\mathrm{Q}_{3}$ - upper quartile, $\mathrm{Me}$ - median, TOC - task-oriented coping style, EOC - emotion-oriented coping style, $\mathrm{AOC}$ - avoidance-oriented coping style, Distraction - engaging in alternative activities, Social Diversion - seeking social contact.

The studies have shown that the dominant stress-coping style was the task-oriented style, which was found in $41.10 \%$ of the subjects. An avoidance-oriented style was found in $21.92 \%$ of the subjects, while an emotion-oriented style was found in $16.10 \%$. In $2.4 \%$ of the subjects, there was no significant difference between the stress-coping styles. Two styles intensified more than the third were observed in $18.49 \%$ of the subjects.

Statistical data analysis has shown that age, sex and place of residence did not significantly affects the adopted stress-coping styles $(p>0.05)$. As for education, there were statistically significant differences in the method of choosing the stress-coping style $(p<0.01)$. Individuals with higher education more frequently adopted the task-oriented style, while those with lower education focused on the other two styles (Table 2).

\section{Table 2. Demographic factors contributing to the choice of a stress-coping style by parents of hospitalized children} \begin{tabular}{l|ll}
\hline Dominant style & Demographic factors contributing to the choice of a stress-coping style
\end{tabular}

\begin{tabular}{|c|c|c|c|c|c|c|c|c|}
\hline \multicolumn{9}{|l|}{ Age } \\
\hline & $N$ & \multicolumn{3}{|l|}{ Rank sum } & \multicolumn{2}{|l|}{ Mean rank } & $\mathrm{H}$ & $p$-value \\
\hline EOC & 47 & \multicolumn{3}{|l|}{$6,736.5$} & \multicolumn{2}{|l|}{143.330} & \multirow{5}{*}{4.767} & \multirow{5}{*}{$>0.05$} \\
\hline$A O C$ & 64 & \multirow{2}{*}{\multicolumn{3}{|c|}{\begin{tabular}{|l|}
$8,347.5$ \\
$18,682.5$ \\
\end{tabular}}} & \multicolumn{2}{|l|}{130.430} & & \\
\hline TOC & 120 & & & & \multicolumn{2}{|l|}{155.688} & & \\
\hline Two styles & 54 & \multicolumn{3}{|l|}{$7,774.5$} & \multicolumn{2}{|l|}{143.972} & & \\
\hline Three styles & 7 & \multicolumn{3}{|l|}{1,237} & \multicolumn{2}{|l|}{176.714} & & \\
\hline \multicolumn{9}{|l|}{ Sex } \\
\hline & \multicolumn{2}{|l|}{ Female } & \multicolumn{4}{|l|}{ Male } & \multirow[t]{2}{*}{$x^{2}$} & \multirow[t]{2}{*}{$p$-value } \\
\hline & \multicolumn{2}{|l|}{$\boldsymbol{N}(\%)$} & \multicolumn{4}{|l|}{$\boldsymbol{N}(\%)$} & & \\
\hline EOC & \multicolumn{2}{|l|}{43 (17.48) } & \multicolumn{4}{|c|}{$4(8.70)$} & \multirow{5}{*}{2.920} & \multirow{5}{*}{$>0.05$} \\
\hline $\mathrm{AOC}$ & \multicolumn{2}{|l|}{$55(22.36)$} & \multicolumn{4}{|c|}{9 (19.57) } & & \\
\hline TOC & \multicolumn{2}{|l|}{$98(39.84)$} & \multicolumn{4}{|c|}{$22(47.83)$} & & \\
\hline Two styles & 44 (17.89) & & $10(21$ & .74) & & & & \\
\hline Three styles & $6(2.44)$ & & $1(15$. & & & & & \\
\hline Education & & & & & & & & \\
\hline & Primary & Vocational & & Secor & dary & Higher & $x^{2}$ & $p$-value \\
\hline & $N(\%)$ & $N(\%)$ & & $N(\%)$ & & $N(\%)$ & & \\
\hline EOC & $4(33.33)$ & $12(26.67)$ & & $14(1$ & $.46)$ & 17 (12.98) & & \\
\hline$A O C$ & $4(33.33)$ & $14(31.11)$ & & $27(2$ & $.96)$ & 19 (14.50) & & \\
\hline TOC & $2(16.67)$ & $9(20.00)$ & & 3813 & $.54)$ & $71(54.20)$ & 27.931 & $<0.01$ \\
\hline Two styles & $2(16.67)$ & 8 (17.78) & & $22(2$ & $.15)$ & 22 (16.79) & & \\
\hline Three styles & $0(0.00)$ & $2(4.44)$ & & $3(2.8$ & & $2(1.53)$ & & \\
\hline Place of resi & & & & & & & & \\
\hline & Village & City/town & 10,000 & City/ & own up to 100,000 & City/town over 100,000 & $x^{2}$ & $p$-value \\
\hline & $N(\%)$ & $\boldsymbol{N}(\%)$ & & $N(\%)$ & & $N(\%)$ & & \\
\hline EOC & $14(19.44)$ & $5(14.71)$ & & $6(11$ & & $22(16.42)$ & & \\
\hline $\mathrm{AOC}$ & $15(20.83)$ & $6(17.65)$ & & $16(3$ & .77) & $27(20.15)$ & & \\
\hline TOC & $26(36.11)$ & $14(41.18)$ & & 2013 & $.46)$ & 60 (44.78) & 6.772 & $>0.05$ \\
\hline Two styles & $16(22.22)$ & $8(23.53)$ & & $9(17$ & & $21(15.67)$ & & \\
\hline Three styles & 1 (1.39) & $1(2.94)$ & & $1(1.9$ & & 4 (2.99) & & \\
\hline
\end{tabular}




\section{Discussion}

The studies have shown that as for the stress-coping strategies parents, depending on sex, show significant differences. According to Goldbeck [7] and Pilarczyk et al. [8], in situations of a child's illness, mothers adopt the emotion-oriented stresscoping style, and fathers often prefer the task-oriented style. A similar result has been demonstrated in the studies of Kózka et al., where was found that in a study group of women, the task-oriented style is present to a lesser degree, and the stresscoping method among the subjects depended on age, gender and professional activity [9]. This has not been confirmed in the authors' study. Regardless of sex, parents presented all types of stress-coping styles. Both among mothers and fathers, the dominant stress-coping style was the task-oriented style - in mothers $39.84 \%$, in fathers $47.83 \%$. The second most common style was that focused on avoidance $-22.36 \%$ of mothers, $19.57 \%$ of fathers. The smallest group was focused on emotions $-17.48 \%$ of mothers, $8.70 \%$ of fathers.

In the authors' study, individuals with higher education amounted to as many as $44.86 \%$ of the subjects. The conducted statistical analysis has shown a significant influence of the subjects' education on the adopted stress-coping style. Individuals with better education were more likely to adopt the task-oriented style. Presumably, this could be related to parents' knowledge and the ability to use it, e.g. for the solving of problems that emerged during a child's illness. However, parents with lower education concentrated on avoidance or emotions. The studies conducted by Aftyka et al. have shown no statistically significant correlation between the level of education of parents of children hospitalized at the Intensive Medical Care Unit and the stress-coping style [10]. In a different study conducted by Podolska and Majewska, it has been found that women with symptoms of perinatal depression, who had Caesarean birth, regardless of their age and education, preferred the emotion-oriented style and substitutional activities when in stressful situations [11].

The conducted studies have shown that the parents' place of residence does not significantly influenced their stress-coping style $(p>0.05)$. Similar conclusions were drawn by authors who studied the caretakers of children hospitalized for short periods [5].

\section{Conclusions}

1. In the situation of a child's illness and hospitalization, parents usually adopt the task-oriented stress-coping style; this is not dependent on their age, gender and place of residence.

2. Parents' education had a significant influence on the adopted style of coping with stress. Highly educated individuals were more likely to adopt the task-oriented style, and those with lower education focused on emotions or avoidance.

Source of funding: This work was funded by the authors' resources.

Conflict of interest: The authors declare no conflict of interests.

\section{References}

1. Mastalerz-Migas A, Koczy M, Stelmaszczyk I, et al. Jak funkcjonuje rodzina z dzieckiem chorym na nowotwór - doniesienia wstępne. Fam Med Prim Care Rev 2011; 13(2): 185-188.

2. Rozenek H, Owczarek K. Padaczka u dziecka i jej wpływ na wybrane aspekty funkcjonowania rodziny. Neurol Dziec 2008; 34: 55-59.

3. Uzzel BP, Stonnington HH, eds. Recovery after traumatic brain injury. Mahwah, New Jersey: Lawrence Erlbaum Associates Publishers; 1996.

4. Treyvaud K, Doyle LW, Lee KJ, et al. Family functioning, burden and parenting stress 2 years after very preterm birth. Early Hum Dev 2011; 87(6): 427-431.

5. Krywda-Rybska D, Zdun-Ryzewska A, Zach E. Stres psychologiczny i czynniki na niego wpływające u opiekunów dziecka krótkotrwale hospitalizowanego. Pediatr Med Rodz 2012; 8(3): 268-271.

6. Strelau J, Jaworowska A, Wrześniewski K, et al. Kwestionariusz radzenia sobie w sytuacjach stresowych. Podręcznik. Warszawa: Pracownia Testów Psychologicznych Polskiego Towarzystwa Psychologicznego; 2005.

7. Goldbeck L. Parental coping with the diagnosis of childhood cancer: gender effects, dissimilarity within couples and quality of life. Psychooncology 2001; 10(4): 325-335.

8. Pilarczyk J, Pawełczak-Szastok M, Wojtasik N, et al. Analiza funkcjonowania psychospołecznego ojców opiekujących się w szpitalu dziećmi z chorobami nowotworowymi. Psychoonkologia 2012; 16(2): 37-42.

9. Kózka M, Wojtan S, Woźniok E. Funkcjonowanie psychospołeczne opiekunów chorych wentylowanych mechanicznie w warunkach domowych. Probl Pielęg 2011; 19(2): 185-193.

10. Aftyka A, Humeniuk E, Rybojad, et al. Style radzenia sobie ze stresem u rodziców dzieci hospitalizowanych w Oddziale Intensywnej Terapii Noworodka. Hygeia Public Health 2015; 50(2): 395-400.

11. Podolska M, Majewska A. Style radzenia sobie w sytuacjach stosowane przez matki w połogu. Klin Perinatol Ginekol 2007; 43(4): 64-76.

Tables: 2

Figures: 0

References: 11

Received: 02.05.2016

Revised: 27.06.2016

Accepted: 27.06.2016

Address for correspondence:

Małgorzata Starczewska, PhD

Zakład Pielęgniarstwa PUM

ul. Żołnierska 48

71-210 Szczecin

Polska

Tel.: +48 91 48-00-910

E-mail:mlary@pum.edu.pl 